This is a pre-copyedited, author-produced version of an article accepted for publication by Elsevier in Ecological Indicators on 2017 following peer review, available online: http://dx.doi.org/10.1016/j.ecolind.2016.12.028.

Original Articles

\title{
Economic growth and environmental impacts: An analysis based on a composite index of environmental damage
}

Thiago Alexandre das Neves Almeida ${ }^{\mathrm{a}, \mathrm{c}, \star}$, Luís Cruz ${ }^{\mathrm{b}}$, Eduardo Barata ${ }^{\mathrm{b}}$, Isabel-María García-Sánchez ${ }^{\mathrm{c}}$

- Federal Untverstty of Camptna Grande, CAPES-Coordenação de Aperfelçoamento de Pessoal de Nivel Superior, R. Aprtgio Veloso, 882, B. Untversttario, Camptna Grande, PB CEP: $58,429-900$, Brazll

b GEMF, CeBER and Faculty of Economics, Untverstty of Cotmbra, Av. Dias da Silva 165, 3004-512 Cotmbra, Portuga

¿Salamanca Untversity, Campus Miguel de Unamuno, Edificto FES, Av. Franctsco Tomás y Vallente, s/n, 37007 Salamanca, Spatn

\section{A R T I C L E I N F O}

\section{Article history:}

Received 14 March 2016

Received in revised form

14 November 2016

Accepted 13 December 2016

\section{Keywords:}

Environmental Kuznets Curve

Environmental composite indexes

Economic growth

GEP

Panel data

\section{A B S T R A C T}

The conflict between economic growth and the environment is complex and sharper today than ever before. Indeed, the relationship between economic growth and the sustainability of ecosystems has been extensively discussed in the literature, but the results remain controversial.

This paper reviews the use of single and composite indicators of environmental damage and questions whether the Environmental Kuznets Curve (EKC) hypothesis sufficiently mirrors the relationship between economic growth and ecological damage. Ecological Indicators are relevant when they potentially inform society about ecological developments in a reliable way. We use the modified composite index of environmental performance (mCIEP) to measure environmental damage, and GDP per capita to represent economic growth. The econometric model is developed using panel data composed of 152 countries and a period of 6 years. The model is estimated for the full sample, for three different sets of countries, by level of development, and a decomposition analysis is carried out, which corresponds to the study of the CIEP individual dimensions.

Our results reveal that, at present, the EKC hypothesis is not proved. We conclude that it is critical to be clear that economic growth alone is not enough to improve environmental quality. Therefore, creating a consistent, coherent and effective environmental policy framework is essential in order to improve environmental quality that supports wellbeing and enables long-term economic development. 2017 Elsevier Ltd. All rights reserved. 


\section{Introduction}

There is the need to balance economic growth and the sustainability of ecosystems. For a long time, scholars have been considering the trade-offs between economic growth and its impact(s) on the ecosystem, and the "Environmental Kuznets Curve Hypothesis" (EKC hypothesis) is one of the most important theories surrounding this relationship.

The EKC hypothesis suggests that the relationship between economic growth and its environmental impacts is not linear; rather, it may be represented by an inverted U-shaped curve. The idea is that economic growth causes negative ecological impacts that initially tend to increase as the economy grows, until they reach a turning point, where the environmental damage stabilizes and begins to fall while economic growth continues. This theory is based on an original principle developed by Kuznets (1955) regarding the relationship between economic growth and income inequality. However, since then, significant progress has been made with regard to testing this hypothesis, mainly in the field of environmental sciences.

The most common econometric models used to analyse the EKC hypothesis are constructed with single variables to represent the (negative) impacts on ecosystems (Xiaoyua et al., 2011). The most commonly used variables to measure environmental damage are: carbon dioxide $\left(\mathrm{CO}_{2}\right)$, sulfur dioxide $\left(\mathrm{SO}_{2}\right)$ and nitrogen oxide $\left(\mathrm{NO}_{\mathrm{x}}\right)$ emissions (Babu and Datta, 2013 and Buehn and Farzanegan, 2013). However, these only measure the effects on air, which represents just one facet of pollution and thus they ignore other relevant dimensions of environmental impacts (Al-Mulali et al., 2015; Jha and Murthy, 2003). But, overall, conclusions on the EKC hypothesis are still unclear and there is a need for additional research that crosses the boundaries of these traditional studies, which use a single environmental variable.

Alternatively, some authors are using composite indicators to measure the environmental impacts, so that they are able to address broader features of ecosystems. However, none of these proposed indexes covers a wide range of ecosystem dimensions. Just as an example, to the best of our knowledge, none of these composite indexes has considered the consequences on human health of environmental damage(s). Furthermore, the amount of research that has used an environmental composite index is still too small to provide consistent conclusions on the actual relationship between economic growth and ecological damage.

Summing up, the vast literature on the EKC hypothesis still presents unclear results. Jha and Murthy (2003) argue that there is no consensus regarding the level of global environmental impacts caused by economic activities. Dinda (2005) affirms that the question of the reliability of the EKC hypothesis has not been completely solved yet. Bo (2011) calls it a "controversial issue". Thus, we have a puzzle that requires further investigation to obtain more congruent and accurate results to support policy makers.

Policy makers are immersed in these confusing and controversial conclusions regarding the relationship between economic growth and environmental impact(s). Ecological indicators become relevant only when they potentially inform society about ecological developments in a reliable and consistent way. Accordingly, there is a need to improve knowledge on the real impacts of economic development on our ecosystem(s) and citizens' wellbeing to support (local, regional and national) policy decision-making and planning processes.

This study aims to fill this research gap and add new viewpoints to the debate on the relationship between economic growth and impacts on the environment, by exploring the use of an 
environmental variable index that allows for accounting for a wide range of environmental damage. More specifically, this paper focuses on the analysis of the relationship between economic development and ecological damage, based on the EKC hypothesis, using an original environmental composite index. To achieve this purpose, the Composite Index of Environmental Performance (CIEP), proposed by García-Sánchez et al. (2015), is used to represent the environmental variable(s). This indicator was developed for countries, based on the driving force-pressure-state-exposure-effect-action (DPSEA) framework, using a set of 19 variables, which include the various ecosystem dimensions: air, water, flora, fauna and soil. Thus, this adds to the literature by expanding the scope of ecosystems impacts measurement, which is widely recognized as one of the main limitations observed in the studies that have used a composite index to analyse the EKC hypothesis. Furthermore, a better understanding of what the real effects of economic growth on the environment are might bring insights that can aid policy makers in making decisions towards the promotion and better harmonization of economic development and ecological quality.

This paper is organized as follows. In the next section, we provide background information on the EKC hypothesis, identifying the most relevant studies that use a composite index to measure environmental impacts. Section 3 explains the Composite Index of Environmental Performance (CIEP), which is to be used in the empirical application. Section 4 introduces the methodology and data. Section 5 presents the results and a discussion on their policy relevance. Section 6 concludes.

\section{The relationship between economic growth and ecological impact(s)}

The impact of economic growth on ecosystems has been widely studied through statistical models, using different variables and approaches. But the conclusions continue to resemble a complex black box. Actually, results have shown that the economic system may put the ecological system(s) under pressure and, as a consequence, damage its own sustainability (Machado et al., 2001).

Economic growth was traditionally seen as 'synonymous' with environmental degradation. However, with the introduction of the sustainable development concept, new approaches have emerged. Researchers are finding that economic growth can also be associated with environmental preservation. Sustainable development can be seen as an approach that aims to pacify the relationship between economic development and ecosystem(s).

\subsection{The Environmental Kuznets Curve hypothesis}

Scholars are observing a non-monotonic behaviour relationship between various pollutants and income (Ahmeda and Long, 2012; Bo, 2011; Jha and Murthy, 2003; Li et al., 2014; Lopez and Mitra, 2000; Mukherjee and Chakraborty, 2013 and Zhao et al, 2013). This observation was first made by Grossman and Krueger (1991), while analysing the North American Free Trade Agreement (NAFTA). They concluded that environmental degradation increases with economic growth, but then, environmental quality begins to improve as economic development increases. In others words, there might be a turning point at which the correlation between economic growth and environmental performance changes direction. This theory is widely known as the Environmental Kuznets Curve (EKC) hypothesis. 
Under these circumstances some paradoxical insights arise. Generally, economic activities use fossil fuels and other natural resources to produce goods and services. Cracolici et al. (2010) claimed that there is a positive correlation between GDP growth and $\mathrm{CO}_{2}$ emissions. In addition, they observed that urbanization, which is a typical phenomenon in economically developed countries, causes a substantial increase in city pollution levels, because both transport and the consumption of resources (such as water and energy) affect the environment.

These issues were also investigated by Brock and Taylor (2010), Inglehart (1995) and Kerret and Shvartzvald (2012). They observed that in developed countries, citizens are more concerned with health care, quality of life and welfare; i.e., they are more eco-conscious. Actually, above certain income levels, citizens become more environmentally responsible and change their behaviour, preferring clean products, regardless of the cost (Bo, 2011; Dinda, 2004 and Morse, 2008). Furthermore, wealthy countries tend to have more financial resources to invest in environmental policies that address environmental disasters and aim to maintain welfare quality standards (Roca, 2003). Industries begin to use cleaner technologies and governments allocate more resources to implement environmental policies. In this regard, Kaika and Zervas (2013) suggest that in the initial phases of economic development, the primary industry is predominant and causes high levels of pollution and consumption of resources. As the economy grows, the quality of technology, services and information improves; thus, the process reduces environmental damage by becoming more resource efficient. Al-Mulali et al. (2015) also agree that technology influences the turning point where environmental degradation begins to decrease, as it can allow for significant improvements in energy efficiency and renewable energy use. Thus, in this regard, high environmental quality can be considered as having the typical characteristics of a luxury good (Bergh, 2009).

\subsection{Testing the EKC hypothesis based on a single environmental variable}

There are several proposals in terms of analyzing the relationship between economic growth and its environmental impact(s). According to Fiorino (2011), in general, the most commonly used variables for measuring economic growth have been income and GDP growth rates (either in absolute and per capita terms). Regarding the variables used to measure environmental damage, the diversity is huge and predominantly one single variable is used, though some approaches make use of index or composite indicators.

The literature shows that the results on the EKC hypothesis are diverse. For example, Ahmeda and Long (2012) found the concept of an inverted U-shaped curve to be true (in Pakistan) only in the long run, while Zhao et al. (2013), also using gas emissions growth rates, reached the opposite conclusion, observing that the EKC hypothesis is widely supported in the short, but not in the long term. On the other hand, other works have proposed curves of different shapes for the relation between economic growth and environmental impacts. Lopez and Mitra (2000) hypothesized a U-shaped curve, but it was not an inverted one. Contrarily to the EKC hypothesis, this means that initially there is a high rate of pollution, then the pollution decreases until a specific level of economic growth, where it increases again. Interestingly, Egli and Steger (2007) found an N-shaped pattern, identifying a second turning point where ecological damage starts increasing again while the economy continues to grow.

It is possible that the lack of consensus in the conclusions about the EKC hypothesis lies in the methodology or in the variables used to construct the models (Stern, 2004). For example, Zhao 
et al. (2013) argue that the EKC hypothesis may be sensitive to countries' specificities and Ahmeda and Long (2012) discuss that time series can influence the relationship. Morse (2008) supposes that this might be due to the quality of the datasets used and of the individuals' selection. The geographical or spatial effects (Tevie et al., 2011) and temporal aspects (Chowdhury and Moran, 2012) can also be pointed out as possibly having an influence on the results. Brajer et al. (2011) and Tevie et al. (2011) mention the use of different variables to measure pollution. Furthermore, Lopez and Mitra (2000) argue that that models have been constructed using inadequate environmental variables and Cleveland et al. (2001) warn about the bias that a single variable can bring, mainly because consumption and production activities generate different types of pollutants, and thus the choice of a single variable can be adequate for some individuals/regions/countries, but not for others, due to differences in the predominant economic activities. In this regard, Brajer et al. (2011) claim that the current concept of pollution should involve several variables, which behave differently, thus making the measurement of environmental impact(s) a difficult task.

Bergh (2009) and Pasten and Figueroa (2012) identify some common evidence in the conclusions of EKC hypothesis studies. They observe that this theory is supported by a specific set of pollutant variables, such as local gas emissions with short run effects (i.e. sulfur and carbon dioxide). On the other hand, the EKC hypothesis is generally rejected by studies that use municipal waste and energy consumption.

Other researchers have used other environmental indicators as dependent variables: threatened species (McPherson and Nieswiadomy, 2005 and Mills and Waite, 2009); water (Lee et al., 2010; Thompson, 2012 and Tsuzuki, 2009) and energy use (Turner and Hanley, 2011); deforestation (or forest) (Chowdhury and Moran, 2012; Koop and Tole, 1999 and Mather et al., 1999); farmland conversion (Li et al., 2014) and industrial waste (Xiaoyua et al., 2011). In common, all of these are single variables, thus providing a short-sighted approach to the real problem associated with the overall impacts on the ecosystems (Caviglia-Harris et al., 2009 and Roca, 2003).

Thus, several authors have criticised the use of a single pollution/environmental variable (Arrow et al., 1995; Boutaud et al., 2006; Mozumder et al., 2006) and argue for the use of an environmental composite index to test the EKC hypothesis, which would allow for the consideration of larger amounts of information, thus covering a richer and wider spectrum of ecosystems' features (Mukherjee and Chakraborty, 2013). This can certainly provide additional insights and bring new perspectives, improving the debate on the relation between economic growth and environmental impact(s), and thus generating conditions for better decision/policy making.

\subsection{Environmental composite indexes and the EKC hypothesis}

It is impossible to capture all of the effects on the various environmental dimensions by using one variable alone. Accordingly, some authors use composite indicators to measure the environmental impacts, so that they are able to address broader aspects of the ecosystems. These proposals may be classified into two main groups, according to the originality of the composite index. The first uses already existing composite indexes (e.g., Al-Mulali et al. (2015); Bagliani et al. (2008); Beça and Santos (2014); Boutaud et al. (2006); Caviglia-Harris et al. (2009); Morse (2008); Mozumder et al. (2006); Mukherjee and Chakraborty (2013); and Wang et al. 
(2013)), while the second gathers those that develop one index with a set of variables that cover more comprehensively information about the ecosystem(s) (e.g., Abou-Ali and Abdelfattah (2013); Babu and Datta (2013); Brajer et al. (2011); Buehn and Farzanegan (2013); Jha and Murthy (2003); Raunikar and Buongiorno (2008); Tevie et al. (2011); and Xiaoyua et al. (2011)).

In this context, Babu and Datta (2013) highlight the relevance of using composite indexes constructed with multidimensional elements, covering several ecological dimensions (air, water, land, fauna and flora). But it is still hard to find studies that have tested the EKC hypothesis by using a composite index to measure environmental degradation (or performance). Table 1 summarizes these studies.

As Table 1 synthesizes most of the studies that consider countries' databases. Regarding the environmental composite index, 53\% of the studies reviewed used an existing indicator (identified by “e”), while 47\% developed their own indicator (identified by “d”). GDP per capita is clearly the most commonly used variable to measure economic growth.

The econometric models are developed based on time series, cross section or panel data and all of the proposals models are polynomial standard models with linear, quadratic and cubic functions to estimate economic growth (measured by GDP or income per capita). Two main types of results have been found: around $47 \%$ of the surveyed studies found significant evidence to support the EKC hypothesis, while the others (53\%) did not find conclusive evidence regarding the inverted U-shaped pattern. Furthermore, another very relevant issue is that none of the papers that use the Ecological Footprint (EF) index - most (55\%) used a composite index in group "e" - support the EKC hypothesis. Actually, in group "e", the majority (66\%) of the papers did not found significant evidence to prove a correlation between economic growth and environmental impact(s). On the other hand, among the group of scholars who developed their own indicator, $63 \%$ of them support the EKC hypothesis.

The studies in Table 1 can be considered to have great relevance, not least because they are among the first to cross the border in EKC hypothesis experiments, proposing the replacement of a single variable with an environmental composite index. But their main drawbacks and limitations are also identified. These can be classified into two main types. On the one hand, there are gaps in the ecological dimensions covered - to gather more complete information, a composite index should consider the full scope of ecological dimensions, namely air, water, soil, fauna and flora. This can be considered to be the main shortcoming in all of the composite indexes, as they only capture a portion of the environmental impact(s). Furthermore, in this regard, Jha and Murthy (2003) claim that composite indexes may be used to synthesize as much of the central tendency as possible (without losing important information and representing a set of vectors/variables with potentially different directions). 
Table 1. Studies using environmental composite indexes to test the EKC hypothesis.

\begin{tabular}{|c|c|c|c|c|c|c|c|c|c|}
\hline Study & $\begin{array}{l}\text { Population } \\
\text { surveyed }\end{array}$ & $\begin{array}{l}\text { Time } \\
\text { series }\end{array}$ & $\begin{array}{l}\text { Environmental } \\
\text { Composite } \\
\text { Index }\end{array}$ & $\begin{array}{c}N^{o} \text { of } \\
\text { variables } \\
\text { used in the } \\
\text { index }\end{array}$ & $\begin{array}{c}\text { Ecosystem's } \\
\text { scope } \\
\text { included }\end{array}$ & $\begin{array}{l}\text { Economic } \\
\text { Growth } \\
\text { variable used }\end{array}$ & Method & $\begin{array}{c}\text { Main results } \\
\text { (Confirm or reject the } \\
\text { EKC hypothesis } \\
\text { and its shape) }\end{array}$ & $\begin{array}{c}\text { Main } \\
\text { drawbacks /limitations }\end{array}$ \\
\hline $\begin{array}{l}\text { Jha and } \\
\text { Murthy } \\
\text { (2003) }\end{array}$ & $\begin{array}{c}174 \\
\text { countries }\end{array}$ & $\begin{array}{l}1990- \\
1996\end{array}$ & $\begin{array}{c}\text { Environmental } \\
\text { Degradation Index } \\
\text { (EDI) }\end{array}$ & 6 & $\begin{array}{l}\text { Water, flora, } \\
\text { air and } \\
\text { resources } \\
\text { consumption }\end{array}$ & $\begin{array}{c}\text { Human } \\
\text { Development } \\
\text { Index (HDI) }\end{array}$ & $\begin{array}{l}\text { Cross } \\
\text { section }\end{array}$ & И & $\begin{array}{l}\text { Gaps on the ecological } \\
\text { dimensions covered }\end{array}$ \\
\hline $\begin{array}{l}\text { Boutaud et } \\
\text { al. }(2006)\end{array}$ & $\begin{array}{c}130 \\
\text { countries }\end{array}$ & 2001 & $\begin{array}{c}\text { Ecological } \\
\text { Footprint (EF) }\end{array}$ & - & - & $\begin{array}{l}\text { GDP per } \\
\text { capita }\end{array}$ & $\begin{array}{l}\text { Cross } \\
\text { section }\end{array}$ & $\begin{array}{c}\text { No conclusive evidence } \\
\text { to support the EKC } \\
\text { hypothesis }\end{array}$ & $\begin{array}{l}\text { Only one year analysed } \\
\text { Gaps on the ecological } \\
\text { dimensions covered } \\
\text { EF is closer to the level of } \\
\text { consumption than that of } \\
\text { environmental damage }\end{array}$ \\
\hline $\begin{array}{l}\text { Mozumder } \\
\text { et al. } \\
(2006)\end{array}$ & $\begin{array}{c}104 \\
\text { countries }\end{array}$ & - & $\begin{array}{c}\text { National } \\
\text { Biodiversity Risk } \\
\text { Assessment Index } \\
\text { (NABRAI) }^{\mathbf{e}}\end{array}$ & $\begin{array}{c}10, \\
\text { grouped in } \\
3 \\
\text { dimensions }\end{array}$ & Biodiversity & $\begin{array}{l}\text { GDP per } \\
\text { capita }\end{array}$ & $\begin{array}{c}\text { Cross } \\
\text { section } \\
\text { Logarithmic } \\
\text { OLS }\end{array}$ & $\begin{array}{c}\text { No conclusive evidence } \\
\text { to support the EKC } \\
\text { hypothesis }\end{array}$ & $\begin{array}{l}\text { Gaps on the ecological } \\
\text { dimensions covered }\end{array}$ \\
\hline $\begin{array}{l}\text { Bagliani et } \\
\text { al. (2008) }\end{array}$ & $\begin{array}{c}141 \\
\text { countries }\end{array}$ & 2001 & $\begin{array}{c}\text { Ecological } \\
\text { Footprint (EF) }\end{array}$ & - & - & GDP & $\begin{array}{c}\text { Cross } \\
\text { section } \\
\text { OLS \& WLS } \\
\text { Standard } \\
\text { and } \\
\text { Logarithmic }\end{array}$ & $\begin{array}{l}\text { No conclusive evidence } \\
\text { to support the EKC } \\
\text { hypothesis }\end{array}$ & $\begin{array}{l}\text { Only one year analysed } \\
\text { Gaps on the ecological } \\
\text { dimensions covered } \\
\mathrm{EF} \text { is closer to the level of } \\
\text { consumption than that of } \\
\text { environmental damage }\end{array}$ \\
\hline $\begin{array}{l}\text { Morse } \\
(2008)\end{array}$ & $\begin{array}{c}141 \\
\text { countries }\end{array}$ & $\begin{array}{l}2001- \\
2005\end{array}$ & $\begin{array}{c}\text { Environmental } \\
\text { Sustainability } \\
\text { Index (ESI) }{ }^{\mathrm{e}} \text { and } \\
\text { Environmental } \\
\text { Pollution Index } \\
\text { (EPI) }^{\mathrm{e}}\end{array}$ & $\begin{array}{l}76, \\
\text { aggregated } \\
\text { in } 22 \\
\text { indexes, } \\
\text { grouped in } \\
4 \text { dimens. }\end{array}$ & $\begin{array}{l}\text { Water, flora, } \\
\text { fauna, air, } \\
\text { and soil }\end{array}$ & $\begin{array}{l}\text { GDP per } \\
\text { capita } \\
\text { (adjusted for } \\
\text { PPP) }\end{array}$ & $\begin{array}{l}\text { Standard } \\
\text { and } \\
\text { logarithmic }\end{array}$ & $\begin{array}{c}\text { ก: pressure x GDP per } \\
\text { capital } \\
\text { U: state x GDP per } \\
\text { capital } \\
\text { У: response x GDP per } \\
\text { capital }\end{array}$ & $\begin{array}{l}\text { Gaps on the ecological } \\
\text { dimensions covered } \\
\text { Analysed three dimensions, } \\
\text { but did not relate to the } \\
\text { complete ESI. }\end{array}$ \\
\hline $\begin{array}{l}\text { Raunikar } \\
\text { and } \\
\text { Buongior- } \\
\text { no (2008) }\end{array}$ & $\begin{array}{l}70 \text { specific } \\
\text { forest } \\
\text { zones from } \\
\text { USA }\end{array}$ & $\begin{array}{l}1961- \\
2005\end{array}$ & $\begin{array}{l}\text { Composite index } \\
\text { based on Forest } \\
\text { Inventory and } \\
\text { Analysis (FIA) }\end{array}$ & 18 & Flora & $\begin{array}{c}\text { Income and } \\
\text { income rates } \\
\text { per capita }\end{array}$ & $\begin{array}{l}\text { Panel data } \\
\text { Logarithm }\end{array}$ & $\cap$ & $\begin{array}{l}\text { Gaps on the ecological } \\
\text { dimensions covered }\end{array}$ \\
\hline $\begin{array}{l}\text { Caviglia- } \\
\text { Harris et al } \\
\text { (2009) }\end{array}$ & $\begin{array}{c}146 \\
\text { countries }\end{array}$ & $\begin{array}{l}1961- \\
2000\end{array}$ & $\begin{array}{c}\text { Ecological } \\
\text { Footprint }(\mathrm{EF})^{e}\end{array}$ & - & - & $\begin{array}{c}\text { GDP } \\
\text { per capita }\end{array}$ & $\begin{array}{l}\text { Panel data } \\
\text { Standard } \\
\text { and Fixed } \\
\text { Effects } \\
\text { OLS }\end{array}$ & $\begin{array}{l}\text { No conclusive evidence } \\
\text { to support the EKC } \\
\text { hypothesis }\end{array}$ & $\begin{array}{l}\text { Gaps on the ecological } \\
\text { dimensions covered } \\
\mathrm{EF} \text { is closer to the level of } \\
\text { consumption than that of } \\
\text { environmental damage }\end{array}$ \\
\hline $\begin{array}{l}\text { Brajer et } \\
\text { al. }(2011)\end{array}$ & $\begin{array}{l}139 \\
\text { Chinese } \\
\text { cities }\end{array}$ & $\begin{array}{l}1990- \\
2006\end{array}$ & $\begin{array}{c}\text { Nemerow index } \\
\text { and health-based } \\
\text { index (with two } \\
\text { versions) }\end{array}$ & 3 & Air & $\begin{array}{l}\text { Real gross } \\
\text { product } \\
\text { per capita }\end{array}$ & $\begin{array}{l}\text { Panel data } \\
\text { Logarithm }\end{array}$ & $\cap$ & $\begin{array}{l}\text { Only Chinese cities } \\
\text { analysed } \\
\text { Gaps on the ecological } \\
\text { dimensions covered }\end{array}$ \\
\hline $\begin{array}{c}\text { Tevie et al. } \\
\text { (2011) }\end{array}$ & $\begin{array}{l}48 \text { US } \\
\text { states }\end{array}$ & 2007 & $\begin{array}{c}\text { Modified National } \\
\text { Biodiversity Risk } \\
\text { Assessment Index } \\
\text { (NABRAI), } \\
\text { (MODEX) }\end{array}$ & $\begin{array}{c}11, \\
\text { grouped in } \\
3 \\
\text { dimensions }\end{array}$ & $\begin{array}{l}\text { Biodiversity } \\
\text { and soil. }\end{array}$ & $\begin{array}{l}\text { Income } \\
\text { per capita }\end{array}$ & $\begin{array}{l}\text { Cross } \\
\text { section } \\
\text { Logarithm } \\
\text { OLS }\end{array}$ & $\begin{array}{l}\text { No conclusive evidence } \\
\text { to support the EKC } \\
\text { hypothesis }\end{array}$ & $\begin{array}{l}\text { Only US states analysed } \\
\text { Gaps on the ecological } \\
\text { dimensions covered }\end{array}$ \\
\hline $\begin{array}{l}\text { Xiaoyua et } \\
\text { al. (2011) }\end{array}$ & $\begin{array}{l}30 \text { Chinese } \\
\text { provinces }\end{array}$ & $\begin{array}{l}2003- \\
2008\end{array}$ & $\begin{array}{l}\text { Environmental } \\
\text { Pollution Index } \\
\text { (EPI) }\end{array}$ & $\begin{array}{l}24 \text { index, } \\
\text { grouped in } \\
6 \\
\text { dimensions }\end{array}$ & $\begin{array}{l}\text { Water, air, } \\
\text { energy } \\
\text { consumption, } \\
\text { solid waste }\end{array}$ & $\begin{array}{c}\text { GDP } \\
\text { per capita }\end{array}$ & Panel data & $\begin{array}{l}\cap \\
\begin{array}{c}\text { (majority of the } \\
\text { provinces) }\end{array}\end{array}$ & $\begin{array}{l}\text { Only Chinese provinces } \\
\text { analysed } \\
\text { Gaps on the ecological } \\
\text { dimensions covered }\end{array}$ \\
\hline $\begin{array}{l}\text { Abou-Ali } \\
\text { and } \\
\text { Abdelfat- } \\
\text { tah (2013) }\end{array}$ & $\begin{array}{c}62 \\
\text { countries }\end{array}$ & $\begin{array}{l}1990- \\
2007\end{array}$ & $\begin{array}{l}\text { Environmental } \\
\text { Quality Index } \\
\text { (EQI) }^{d}\end{array}$ & $\begin{array}{l}3 \text {, grouped } \\
\text { in } 2 \\
\text { dimensions }\end{array}$ & $\begin{array}{l}\text { Air, energy } \\
\text { and ozone } \\
\text { depleting } \\
\text { substances } \\
\text { consumption }\end{array}$ & $\begin{array}{c}\text { GDP } \\
\text { per capita }\end{array}$ & Panel data & $\cap$ & $\begin{array}{l}\text { Gaps on the ecological } \\
\text { dimensions covered }\end{array}$ \\
\hline $\begin{array}{l}\text { Babu and } \\
\text { Datta } \\
(2013)\end{array}$ & $\begin{array}{c}22 \\
\text { developing } \\
\text { countries }\end{array}$ & $\begin{array}{c}1980 \\
- \\
2008\end{array}$ & $\begin{array}{c}\text { Environmental } \\
\text { Degradation Index } \\
\text { (EDI) }\end{array}$ & 5 & $\begin{array}{l}\text { Air, water, } \\
\text { soil, flora and } \\
\text { resources } \\
\text { availability }\end{array}$ & $\begin{array}{c}\text { GDP per } \\
\text { capita and } \\
\text { Development } \\
\text { Balance } \\
\text { Index (DBI) }\end{array}$ & Panel data & $\mathbf{N}$ & $\begin{array}{l}\text { Gaps on the ecological } \\
\text { dimensions covered }\end{array}$ \\
\hline $\begin{array}{c}\text { Buehn and } \\
\text { Farzanegan } \\
(2013)\end{array}$ & $\begin{array}{c}122 \\
\text { countries }\end{array}$ & $\begin{array}{c}1985 \\
- \\
2005\end{array}$ & $\begin{array}{l}\text { Multiple Indicators } \\
\text { Multiple Causes } \\
\text { (MIMIC) }\end{array}$ & 3 & Air & $\begin{array}{c}\text { GDP } \\
\text { per capita }\end{array}$ & $\begin{array}{l}\text { Pooled } \\
\text { cross } \\
\text { section } \\
\text { Logarithm }\end{array}$ & $\cap$ & $\begin{array}{l}\text { Gaps on the ecological } \\
\text { dimensions covered }\end{array}$ \\
\hline $\begin{array}{l}\text { Mukherjee } \\
\text { and } \\
\text { Chakrabor- } \\
\text { ty }(2013)\end{array}$ & $\begin{array}{l}146 \\
\text { countries }\end{array}$ & $\begin{array}{l}2007 \\
- \\
2008\end{array}$ & $\begin{array}{l}\text { Environmental } \\
\text { Pollution Index } \\
\quad \text { (EPI) }\end{array}$ & $\begin{array}{c}76, \\
\text { aggregated } \\
\text { in } 22 \\
\text { indexes, } \\
\text { grouped in } \\
4 \text { dimens. }\end{array}$ & $\begin{array}{l}\text { Water, flora, } \\
\text { fauna, air, } \\
\text { and soil }\end{array}$ & $\begin{array}{c}\text { GDP } \\
\text { per capita }\end{array}$ & $\begin{array}{l}\text { Cross } \\
\text { section }\end{array}$ & $\cap$ & $\begin{array}{l}\text { Gaps on the ecological } \\
\text { dimensions covered }\end{array}$ \\
\hline $\begin{array}{c}\text { Wang et al. } \\
\text { (2013) }\end{array}$ & $\begin{array}{c}150 \\
\text { countries }\end{array}$ & 2005 & $\begin{array}{c}\text { Ecological } \\
\text { Footprint of } \\
\text { consumption and } \\
\text { production (besides } \\
\text { Biocapacity) }\end{array}$ & $s$ & - & $\begin{array}{c}\text { GDP } \\
\text { per capita }\end{array}$ & $\begin{array}{l}\text { Cross } \\
\text { section } \\
\text { OLS }\end{array}$ & $\begin{array}{c}\text { No conclusive evidence } \\
\text { to support the EKC } \\
\text { hypothesis }\end{array}$ & $\begin{array}{l}\text { A welfare index is used, } \\
\text { instead of an environmental } \\
\text { index } \\
\text { Gaps on the ecological } \\
\text { dimensions covered }\end{array}$ \\
\hline $\begin{array}{l}\text { Beça and } \\
\text { Santos } \\
(2014)\end{array}$ & $\begin{array}{l}\text { Portugal } \\
\text { and USA }\end{array}$ & $\begin{array}{c}1960 \\
- \\
2010\end{array}$ & $\begin{array}{c}\text { Index of } \\
\text { Sustainable } \\
\text { Economic Welfare } \\
\text { (ISEW) }\end{array}$ & - & - & GDP & Time series & $\begin{array}{l}\text { Portugal: EKC not } \\
\text { observed } \\
\text { USA: partial and limited } \\
\text { support of the EKC }\end{array}$ & $\begin{array}{l}\text { Only two countries are } \\
\text { compared and used a } \\
\text { sustainability index. } \\
\text { Gaps on the ecological } \\
\text { dimensions covered }\end{array}$ \\
\hline $\begin{array}{l}\text { Al-mulali } \\
\text { et al. } \\
(2015)\end{array}$ & $\begin{array}{c}93 \\
\text { countries }\end{array}$ & $\begin{array}{c}1980 \\
- \\
2008\end{array}$ & $\begin{array}{c}\text { Ecological } \\
\text { Footprint (EF) }\end{array}$ & - & - & $\begin{array}{l}\text { GDP } \\
\text { growth }\end{array}$ & Panel data & $\begin{array}{l}\text { ก: valid for upper, } \\
\text { middle, } \\
\text { and high-income } \\
\text { countries }\end{array}$ & $\begin{array}{l}\text { Gaps on the ecological } \\
\text { dimensions covered } \\
\mathrm{EF} \text { is closer to the level of } \\
\text { consumption than that of } \\
\text { environmental damage }\end{array}$ \\
\hline
\end{tabular}

d) Developed a new composite index. ${ }^{\text {e) }}$ Used an existing composite index. PCA: Principal Component Analysis; GDP: Gross Domestic Product; OLS: Ordinary Least Square; WLS: Weighted Least Square; EKC: Environmental Kuznets Hypothesis; И: Inverted N-shape; $\mathrm{N}$ : N-shape; $\cap$ : Inverted U-shaped curve; U: U-shaped curve; ๖: Linear decrease; -: unavailable information. 
Additionally, the composite indicator(s) should include the cause and effects on human health and on the ecosystem, but the methodologies used to develop these indicators do not acknowledge the cause-effect-consequence, the damage stock and the actions needed to repair the environmental impacts (see Schirnding (2002) and OECD (2008) for further details on frameworks to construct composite indexes). For example, the Ecological Footprint is a composite index closer to the level of consumption than that of environmental damage, and thus does not cover the full extent of ecosystems (Boutaud et al., 2006).

On the other, the main methodological weakness found concerns the choice of cross-section or time-series. Nearly half of the studies compiled in Table 1 were developed using cross-section analysis, but this is limited in this context as it assumes that all countries hold the same characteristics and behaviour regarding economic growth and its consequences on the ecosystem (Borghesi, 1999). Indeed, some of these limitations can be overcome by using panel data. Actually, around $71 \%$ of the models processed with panel data found evidence that supports the EKC hypothesis. One can argue that panel data is more robust, particularly in this context, as it is possible to control the heterogeneity across units and it also allows for more flexibility when analysing behaviour between individuals. Furthermore, it increases the degree of freedom and decreases the collinearity problems between exploratory variables, improving the efficiency of the econometric model while accepting more complex models than the crosssectional or time-series models. Also, panel data allows for controlling of unobservable variables (i.e. that the researcher cannot measure) and variables that change over time, but not across individuals (see Abou-Ali and Abdelfattah (2013) and Xiaoyua et al. (2011), for further details on the advantages of using panel data in the context of this analysis).

\section{Environmental performance by country: The CIEP Model}

Given the limits found in terms of the studies that have already tested the EKC hypothesis, either by using a single or a composite index to measure environmental impacts, we propose the use of a new composite index, with the potential to represent environmental performance in a form that considers the wide spectrum of the ecological dimensions. This is the Composite Index of Environmental Performance (CIEP), which has been developed to measure countries' environmental performance, and is based on the driving force-pressure-state-exposure-effectaction (DPSEEA) approach. This methodology was proposed by the World Health Organization (WHO), linking health, environmental and economic development issues (Schirnding, 2002). The method used for creating the CIEP was structured in seven stages (OECD, 2008; OECD, 2011): i) the development of a theoretical framework; ii) the selection of variables; iii) the imputation of missing data; iv) the removal of variables; v) the normalization of data; vi) weighting; and vii) aggregation. The most appropriate technique was chosen at each stage, based on the data set, the proposed goal and, most importantly, the theoretical framework. In the first stage, the multiple imputation methodology was used to complete the missing data. For normalization, the Johnson transformation was applied (Yeo and Johnson, 2000). In the last phase, weighting and aggregation were performed using the CRITIC (Criteria Importance Through Inter-criteria Correlation) method (Diakoulaki et al., 1995). For further details on the methodology used in deriving the CIEP and the environmental performance by country, see García-Sánchez et al. (2015). 
Accordingly, the CIEP index is constructed using 19 individual indicators (see Table 2), grouped into 5 dimensions, subsequently synthesized in the final composite indicator for a sample of 152 countries (the CIEP index database is available for (free) download in www.indexciep.org).

Table 2. CIEP variables.

\begin{tabular}{|c|c|c|c|}
\hline$N$ & Abbrev. & Variables & DPSEEA \\
\hline 1 & AW & Access to drinking water & $\mathrm{A}$ \\
\hline 2 & AS & Access to sanitation & A \\
\hline 3 & EPfRS & Renewable electricity & A \\
\hline 4 & WaTMProt & Territorial marine area waters protected & A \\
\hline 5 & PopDen & Population density & $\mathrm{DF}$ \\
\hline 6 & GDP & Per capita income & DF \\
\hline 7 & UrPopGr & Urban population growth & DF \\
\hline 8 & ChMor & Child mortality & Ef \\
\hline 9 & DeaR & General mortality & Ef \\
\hline 10 & LiEB & Life expectancy at birth & Ef \\
\hline 11 & AP & Agricultural production & $\mathrm{P}$ \\
\hline 12 & CerPd & Cereal production & $\mathrm{P}$ \\
\hline 13 & $\mathrm{EmCO} 2$ & $\mathrm{CO}_{2}$ emissions & $\mathrm{P}$ \\
\hline 14 & EnUse & Energy intensity (energy use) & $\mathrm{P}$ \\
\hline 15 & EnProd & Energy production & $\mathrm{P}$ \\
\hline 16 & MCAP & Marine capture and aquaculture production & $\mathrm{P}$ \\
\hline 17 & FertUse & Use of fertilizers per unit of agricultural land area & $\mathrm{P}$ \\
\hline 18 & $\mathrm{AL}$ & Agricultural land & $\mathrm{S}$ \\
\hline 19 & HydDis & Hydrological disasters & $\mathrm{S}$ \\
\hline
\end{tabular}

Legend: A - Action; DF - Driving Force, Ef - Effect, P - Pressure, S - State.

Source: García-Sánchez et al. (2015)

Furthermore, it is relevant to highlight some advantages of using the CIEP Model to analyse the EKC hypothesis, as follows: i) the fact that it measures the causal (cause-effect) relationships between human health and the ecosystem (and between the other variables used); ii) the high scope and quality of the information, as it was developed based on the DPSEEA framework; and iii) the capability to account for all of the ecological dimensions: water, air, soil, fauna and flora. Furthermore, the CIEP Model can be comparable across time and countries, thus allowing for taking advantage of using panel data. Concerning the limitations of the CIEP Model, it should be noted that it does not include the indicator of the "exposure" phenomenon, due to the lack of available data in the different data sets. Nevertheless, this limitation does not greatly influence the quality of the model, since the final information is the set of all of the data weighted and aggregated into a single index (García-Sánchez et al., 2015: 174-175).

\section{Methodology and data}

The primary data were extracted from the World Bank (WB) database, and analysed using panel data that includes 152 countries and a period of 6 years. The calculations were made using the Stata 13 statistical software. Departing from the estimation performed in García-Sánchez et al. (2015), two main adjustments were performed prior to its use to test the EKC hypothesis. The first one was the removal of GDP from the original CIEP. Actually, as GDP is used as an explicative variable in the econometric model to analyse the EKC hypothesis, this procedure is required to avoid multicollinearity problems. The second modification was to normalize the modified CIEP ( $m C I E P$ ), changing the values from 0 to 1 in a decreasing scale, in order to 
modify the approach from positive (performance) to negative (damage). Consequently, the index should be interpreted as follows: the higher scores, the worse the performance. GDP is also normalized from a value of 0 to 1 . In any case, these adaptations do not cause changes in the CIEP dimensions' structure. Thus, this research works with the $m C I E P$, which corresponds to the consideration of these 2 adjustments in the original CIEP.

Equation (1) represents the econometric model proposed to test the EKC hypothesis. Actually, the $m C I E P_{i t}$ measures the environmental performance according to the explicative variables presented below:

$$
m C I E P_{i t}=\alpha+\beta_{1} G D P_{i t}+\beta_{2}\left(G D P_{i t}\right)^{2}+\beta_{3}\left(G D P_{i t}\right)^{3}+\varphi_{i}+\varphi_{t}+\varepsilon_{i t}
$$

where, $i$ is the cross section (152 countries), $t$ is the time series (6 years) and $\alpha$ is the constant. The $m C I E P_{i t}$ is the environmental damage and $G D P_{i t}$ is the independent variable, tested in linear, quadratic and cubic functions. $\varphi_{i}$ and $\varphi_{t}$ are dummies used to measure individuals and time effects, respectively. Eit is the random effect. This model follows the standard regression approach that is usually applied (e.g., Al-Mulali et al., 2015; Jha and Murthy, 2003; Kaika and Zervas, 2013; Li et al., 2014; Mukherjee and Chakraborty, 2013; Stern, 2004).

Furthermore, in a first round of estimations, the model is tested for the full sample (152 countries, 6 years); Secondly, it is estimated for three different sets, by level of development (i.e., developed $=46$ countries, developing $=45$ countries and underdeveloped $=61$ countries, all with observations for 6 years), to analyse the influence of this factor on the relationship. Finally, a decomposition analysis is carried out, which corresponds to the study of the CIEP individual dimensions. Morse (2008) deconstructed the Environmental Sustainability Index (ESI) to analyse the relationship between the ESI and economic development, removing the elements that reduce ecological impact. The same econometric model is used, but the dependent variable is replaced by the normalized dimensions that increase ecological damage, namely: driving-force $(m d f)$; pressure $(m p)$ and effects (mef). Then, it is performed for each dimension, aggregating them in factors with the use of Principal Component Analysis (PCA). Abdelfattah and Abou-Ali (2013) also used an econometric model based on this methodology to aggregate the Millennium Development Goals (MDG) variables and analyse the relationship between the sustainable development index and economic development.

The $\beta$ coefficients obtained should be interpreted as shown in Table 3:

Table 3. EKC hypothesis and interpretations.

\begin{tabular}{l|l}
\hline \multicolumn{1}{c|}{ Coefficients } & \multicolumn{1}{c}{ Interpretation } \\
\hline$\beta_{1}>0$ and $\beta_{2}=\beta_{3}=0$ & Monotonically increasing linear correlation. \\
$\beta_{1}<0$ and $\beta_{2}=\beta_{3}=0$ & Monotonically decreasing linear correlation. \\
$\beta_{1}>0, \beta_{2}<0$ and $\beta_{3}=0$ & Quadratic correlation. Inverted U-shaped pattern. \\
$\beta_{1}>0, \beta_{2}<0$ and $\beta_{3}>0$ & Cubic polynomial correlation. N-shaped pattern. \\
\hline \multicolumn{2}{l}{ Source: Adapted from Babu and Datta (2013). }
\end{tabular}

A similar analysis has been considered by the majority of the research in this field (e.g., AlMulali et al., 2015; Jha and Murthy, 2003; Kaika and Zervas, 2013; Li et al., 2014; Mukherjee and Chakraborty, 2013). If the EKC hypothesis is supported, the turning point can be calculated according to the following expression (Dinda, 2004):

$$
x^{*}=-\beta_{1} / 2 \beta_{2} \quad \text { or } \quad x^{*}=\exp \left(-\left(\beta_{1} / 2 \beta_{2}\right)\right) \text { for the logarithmic function }
$$




\section{Results and discussion}

\subsection{Economic growth and its impact on the environment}

First, the analysis is carried out with the country dummy $\left(d_{i}\right)$, thereby recognizing the individual characteristics of each unit. Previously, the possible presence of autocorrelation between the variables, endogeneity, multicollinearity and heteroscedasticity was tested. Based on these procedures, the most adequate estimate is the Generalized-Least Square (GLS), due to possible autocorrelation in the residuals and the variance of the error, which is different across countries. Furthermore, the dataset does not reject the presence of a heteroskedasticity problem. However, the model is estimated in pooled, fixed, random and GLS effect regressions, in order to compare the results. The dataset statistics and correlation coefficients of the variables are shown in Tables 4 and 5, respectively.

Table 4. Statistics of the econometric model.

\begin{tabular}{l|rccrr}
\hline \multicolumn{1}{c|}{ Variable } & Obs & Mean & Std. Dev. & Min & Max \\
\hline mciep & 912 & 0.4693012 & 0.1637376 & 0 & 1 \\
gdp & 906 & 0.1227804 & 0.1862042 & 0 & 1 \\
gdp2 & 906 & 0.0497088 & 0.1226517 & 0 & 1 \\
gdp3 & 906 & 0.0274633 & 0.0929507 & 0 & 1 \\
\hline
\end{tabular}

Legend: mciep - Modified CIEP; gdp - Gross Domestic Product; gdp2 and gdp3 - gdp in quadratic and cubic functions, respectively.

Table 5. Coefficient correlation.

\begin{tabular}{|c|c|c|c|c|}
\hline & mciep & $g d p$ & gdp2 & gdp3 \\
\hline \multirow[t]{2}{*}{ mciep } & 1 & & & \\
\hline & 912 & & & \\
\hline \multirow{3}{*}{ gdp } & $-0.4469 *$ & 1 & & \\
\hline & 0 & & & \\
\hline & 906 & 906 & & \\
\hline \multirow{3}{*}{ gdp2 } & $-0.3517 *$ & $0.9363^{*}$ & 1 & \\
\hline & 0 & 0 & & \\
\hline & 906 & 906 & 906 & \\
\hline \multirow{3}{*}{ gdp3 } & $-0.2824^{*}$ & $0.8171^{*}$ & $0.9624^{*}$ & 1 \\
\hline & 0 & 0 & 0 & \\
\hline & 906 & 906 & 906 & 906 \\
\hline
\end{tabular}

According to Table 5, GDP has a significant and negative effect on $m$ CIEP; but, as GDP grows, the intensity decreases. This means that GDP growth lowers ecological damage in countries. Figure 1 illustrates this correlation and the trend line.

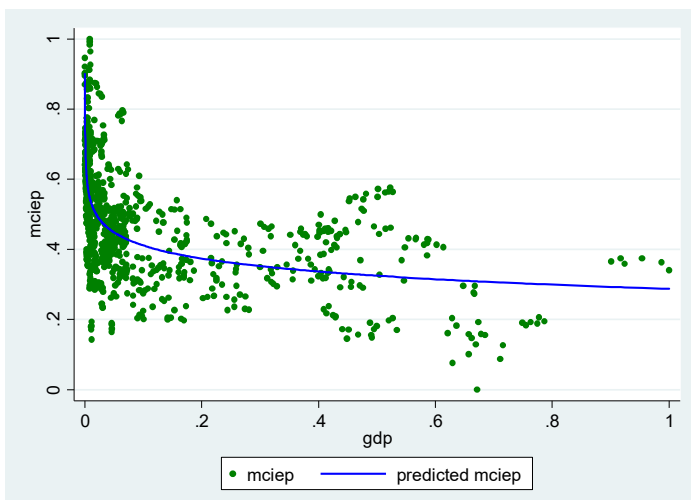

Figure 1. Trend line among the $m C I E P$ and GDP. 
Analysing Figure 1, it is possible to identify a higher concentration between 0 and 0.2 GDP, which suggests that there is a wider spread between the richest countries. The regression results are shown in Table 6, without the countries' dummy coefficients (due to the amount of individuals analysed) (the complete table can be found in Appendix A).

Table 6. Coefficient of pooled, fixed, random and GLS effects regressions - complete econometric model.

\begin{tabular}{|c|c|c|c|c|c|}
\hline Variable & Po & $f e$ & re & mle & gls \\
\hline gdp & -0.56791809 & -0.56791809 & -0.56791809 & -0.56791809 & $-.41589519^{*}$ \\
\hline $\operatorname{gdp} 2$ & 0.60680539 & 0.60680539 & 0.60680539 & 0.60680539 & 0.33444079 \\
\hline gdp3 & -0.23922776 & -0.23922776 & -0.23922776 & -0.23922776 & -0.11206986 \\
\hline $\mathrm{dt} 1$ & 0.00101705 & 0.00101705 & $.01389097 * *$ & $.01389097 * * *$ & $.01318817 * * *$ \\
\hline $\mathrm{dt} 2$ & (omitted) & (omitted) & $.01287392 * *$ & $.01287392 * * *$ & $.01523149 * * *$ \\
\hline $\mathrm{dt} 3$ & -0.00414687 & -0.00414687 & $.00872705^{*}$ & $.00872705^{*}$ & $.00998601 * * *$ \\
\hline $\mathrm{dt} 4$ & -0.00332997 & -0.00332997 & $.00954396^{*}$ & $.00954396 * *$ & $.01013752 * * *$ \\
\hline $\mathrm{dt} 5$ & -0.00420686 & -0.00420686 & $.00866707^{*}$ & $.00866707^{*}$ & $.00819414^{* * *}$ \\
\hline dt6 & $-.01287392 * *$ & $-.01287392 * *$ & (omitted) & (omitted) & (omitted) \\
\hline cons & $.91013861 * * *$ & $.51846305^{* * *}$ & $.54473322 * * *$ & $.54473322 * * *$ & $.54374853 * * *$ \\
\hline $\mathrm{N}$ & 906 & 906 & 906 & 906 & 906 \\
\hline $\mathrm{r} 2$ & 0.96478721 & 0.03265235 & & & \\
\hline r2_a & 0.95733925 & -0.17195398 & & & \\
\hline EKC Hypothesis & $\varnothing$ & $\varnothing$ & $\varnothing$ & $\varnothing$ & 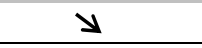 \\
\hline
\end{tabular}

Legend: * $<<0.05 ; * * \mathrm{p}<0.01 ; * * * \mathrm{p}<0.001$; po - pooled; fe - fixed effects; re - random effects;

mle - maximum-likelihood estimation; gls - generalized-least square; gdp - Gross Domestic Product;

gdp2 and gdp3 - gdp in quadratic and cubic functions, respectively.

Based on the GLS model outputs in Table 6, the GDP has a negative coefficient with 95\% significance. This means that ecological damage is reduced (even) in the earliest stage of economic development. The other variables do not have significant coefficients; thus, nothing can be stated about them. According to these results, the $m C I E P$ scores do not support the EKC Hypothesis. In other words, through the $m C I E P$, it cannot be confirmed that high (economic) development can be beneficial to the ecosystem(s). On the other hand, all of the time dummies were found to have significant estimated coefficients, with positive effects in all estimations. Similar results have been proposed by Bagliani et al. (2008), Boutaud et al. (2003), CavigliaHarris et al. (2009), Mozumder et al. (2006) and Tevie et al. (2011), who also found no conclusive evidence to support the EKC Hypothesis using environmental composite indexes.

\subsection{Economic growth and environmental impacts considering countries' level of development}

The econometric model is then performed by considering the different levels of development, in order to observe the behaviour for each group. Three levels of economic development were selected, based on the World Bank classification: developed, developing and underdeveloped countries. Thus, it is possible to observe the influence of the level of development on ecological damage. The sample classification is shown in Table 7.

Table 7. Economic development level (World Bank classification).

\begin{tabular}{|c|c|c|c|}
\hline devlev & Freq. & Percent & Cum. \\
\hline Developed & 276 & 30.3 & 30.3 \\
\hline Developing & 270 & 29.6 & 59.9 \\
\hline Underdeveloped & 366 & 40.1 & 100 \\
\hline Total & 912 & 100 & \\
\hline
\end{tabular}


Most of the countries analysed (40.1\%) are classified as (economically) underdeveloped. The remaining sample is composed of developed and developing countries, with almost equal proportions. The estimated outputs are show in Table 8 (the complete table can be found in Appendix B).

Table 8. Estimated coefficients considering countries' level of development.

\begin{tabular}{|c|c|c|c|c|c|}
\hline \multicolumn{6}{|c|}{ Developed } \\
\hline Variable & dev_po & $d e v \_f e$ & dev_re & dev_mle & dev_gls \\
\hline gdp & -0.49052168 & -0.49052168 & -0.49052168 & -0.49052168 & -0.22113415 \\
\hline gdp2 & 0.40155935 & 0.40155935 & 0.40155935 & 0.40155935 & -0.19873845 \\
\hline $\operatorname{gdp} 3$ & -0.13735395 & -0.13735395 & -0.13735395 & -0.13735395 & 0.21751 \\
\hline $\mathrm{dt} 1$ & 0.00428088 & 0.00428088 & $.0206065 * * *$ & $.0206065 * * *$ & $.01853169 * * *$ \\
\hline $\mathrm{dt} 2$ & $.01044411^{*}$ & $.01044411 *$ & $.02676973 * * *$ & $.02676973 * * *$ & $.02679096 * * *$ \\
\hline $\mathrm{dt} 3$ & 0.00048132 & 0.00048132 & $.01680694 * * *$ & $.01680694 * * *$ & $.01673598 * * *$ \\
\hline $\mathrm{dt} 4$ & 0.00451114 & 0.00451114 & $.02083676^{* * *}$ & $.02083676^{* * *}$ & $.01987363 * * *$ \\
\hline $\mathrm{dt} 5$ & (omitted) & (omitted) & $.01632562 * * *$ & $.01632562 * * *$ & $.01332677 * * *$ \\
\hline dt6 & $-.01632562 * *$ & $-.01632562 * *$ & (omitted) & (omitted) & (omitted) \\
\hline cons & $.58349998 * * *$ & $.47278698 * * *$ & $.45103268 * * *$ & $.45103268 * * *$ & $.43724888 * * *$ \\
\hline \multicolumn{6}{|l|}{ Statistics } \\
\hline $\mathrm{N}$ & 276 & 276 & 276 & 276 & 276 \\
\hline r2 & 0.9674144 & 0.17747258 & & & \\
\hline $\begin{array}{r}\text { r } 2 \text { a } \\
\text { cons }\end{array}$ & 0.95963495 & -0.01889658 & & $.02024372 * * *$ & \\
\hline$\overline{\mathrm{EKC}}$ Hypothesis & $\varnothing$ & $\varnothing$ & $\varnothing$ & $\varnothing$ & $\varnothing$ \\
\hline \multicolumn{6}{|c|}{ Developing } \\
\hline Variable & din_po & din_fe & din_re & din_mle & din_gls \\
\hline gdp & -0.31151262 & -0.31151262 & -0.31151262 & -0.31151262 & -1.2197163 \\
\hline $\operatorname{gdp} 2$ & -1.4046168 & -1.4046168 & -1.4046168 & -1.4046168 & 2.2366716 \\
\hline gdp3 & 2.4151499 & 2.4151499 & 2.4151499 & 2.4151499 & -1.2522125 \\
\hline $\mathrm{dt} 1$ & 0.01293189 & 0.01293189 & 0.01293189 & 0.01293189 & $.00795307 *$ \\
\hline $\mathrm{dt} 2$ & 0.00540962 & 0.00540962 & 0.00540962 & 0.00540962 & 0.00297975 \\
\hline $\mathrm{dt} 3$ & 0.00119887 & 0.00119887 & 0.00119887 & 0.00119887 & -0.00063787 \\
\hline $\mathrm{dt} 4$ & 0.00718598 & 0.00718598 & 0.00718598 & 0.00718598 & $.0064356^{*}$ \\
\hline $\mathrm{dt} 5$ & 0.00221528 & 0.00221528 & 0.00221528 & 0.00221528 & 0.00440857 \\
\hline dt6 & (omitted) & (omitted) & (omitted) & (omitted) & (omitted) \\
\hline cons & $.40239708 * * *$ & $.46237761 * * *$ & $.59323369 * * *$ & $.59323369 * * *$ & $.63995907 * * *$ \\
\hline \multicolumn{6}{|l|}{ Statistics } \\
\hline $\mathrm{N}$ & 270 & 270 & 270 & 270 & 270 \\
\hline r2 & 0.97155052 & 0.06343834 & & & \\
\hline $\begin{array}{l}\text { r2_a } \\
\text { cons }\end{array}$ & 0.96473314 & -0.16099119 & & $.02210349 * * *$ & \\
\hline EKC Hypothesis & $\varnothing$ & $\varnothing$ & $\varnothing$ & $\varnothing$ & $\varnothing$ \\
\hline \multicolumn{6}{|c|}{ Underdeveloped } \\
\hline Variable & und_po & und_fe & und_re & und_mle & und_gls \\
\hline gdp & -13.411068 & -13.411068 & $-13 . \overline{4} 11068$ & -13.411068 & -5.1693472 \\
\hline gdp2 & 545.77462 & 545.77462 & 545.77462 & 545.77462 & 329.17258 \\
\hline gdp3 & -7530.9675 & -7530.9675 & -7530.9675 & -7530.9675 & $-5381.0933^{*}$ \\
\hline dt1 & 0.00463269 & 0.00463269 & 0.00463269 & 0.00463269 & $.00870397 * *$ \\
\hline $\mathrm{dt} 2$ & 0.00407729 & 0.00407729 & 0.00407729 & 0.00407729 & $.00697985^{*}$ \\
\hline dt3 & 0.00565098 & 0.00565098 & 0.00565098 & 0.00565098 & $.00724364 * *$ \\
\hline $\mathrm{dt} 4$ & 0.00158111 & 0.00158111 & 0.00158111 & 0.00158111 & 0.002999 \\
\hline dt5 & 0.00748202 & 0.00748202 & 0.00748202 & 0.00748202 & $.00621096^{*}$ \\
\hline dt6 & (omitted) & (omitted) & (omitted) & (omitted) & (omitted) \\
\hline cons & $.58509563 * * *$ & $.63511026 * * *$ & $.58509563 * * *$ & $.58509563 * * *$ & $.55969362 * * *$ \\
\hline \multicolumn{6}{|l|}{ Statistics } \\
\hline $\mathrm{N}$ & 360 & 360 & 360 & 360 & 360 \\
\hline r2 & 0.93495487 & 0.01371867 & & & \\
\hline $\begin{array}{l}\text { r2_a } \\
\text { cons }\end{array}$ & 0.92003013 & -0.21258561 & & $.04076368 * * *$ & \\
\hline$\overline{E K C ~ H y p o t h e s i s ~}$ & $\varnothing$ & $\varnothing$ & $\varnothing$ & $\varnothing$ & $y$ \\
\hline
\end{tabular}

Legend: $* \mathrm{p}<0.05 ; * * \mathrm{p}<0.01 ; * * * \mathrm{p}<0.001$; po - pooled; fe - fixed effects; re - random effects; mle - maximum-likelihood estimation; gls - generalized-least square; dev - developed countries; din - developing countries; und - underdeveloped countries; gdp - Gross Domestic Product; gdp2 and gdp3 - gdp in quadratic and cubic functions, respectively. 
As expressed in Table 8, the estimated coefficient of the highest GDP is negative, with 95\% significance. This means that ecological damage is reduced in the latest stage of economic growth for underdeveloped countries. The other GDP estimated coefficients are not significant; thus, no conclusions can be made about them. For the remaining levels of development, none of the coefficients are significant. Again, the results show that, through the $m C I E P$, it is not possible to support the EKC hypothesis, even when considering the countries' level of development. These outputs do not prove that in the highest levels of economic development the environmental damage decreases, even when it is measured by the $m C I E P$, which is composed of several ecological variables. Differently, Al-Mulali et al. (2015), using the Ecological Footprint as an environmental index, and considering economic development effects in the analysis, found an inverted U-shaped curve for upper-middle and high-income countries (though they used a different classification for the level of development).

\subsection{CIEP's individual dimensions and the principal component analysis (PCA)}

The CIEP model combines multidimensional variables, which have vectors with different directions. For example, the actions dimension concerns policies that reduce environmental impacts, while the driving-force increases the environmental damage. Thus, and in order to observe the relationship between economic growth and environmental impacts, excluding elements that can improve the ecosystem's quality, only the CIEP dimensions that cause negative impacts are considered. Furthermore, principal component analysis (PCA) is used to construct factors for studying the relationship between the CIEP dimensions and economic growth. The statistics and coefficient correlation between $m C I E P$ and the dimension itself are presented in Tables 9 and 10, respectively.

Table 9. Modified CIEP statistics.

\begin{tabular}{l|ccccc}
\hline \multicolumn{1}{c}{ Variable } & Obs & Mean & Std. Dev. & Min & Max \\
\hline mciep & 912 & 0.4693012 & 0.1637376 & 0 & 1 \\
mdf & 912 & 0.3615380 & 0.1489934 & 0 & 1 \\
mp & 912 & 0.4884669 & 0.1480068 & 0 & 1 \\
ms & 912 & 0.6099734 & 0.1867623 & 0 & 1 \\
mef & 912 & 0.5230459 & 0.1718984 & 0 & 1 \\
ma & 912 & 0.4967051 & 0.1827887 & 0 & 1 \\
\hline
\end{tabular}

Legend: mciep - modified CIEP; mdf - modified driving-force; $\mathrm{mp}$ - modified pressure; ms - modified state; mef - modified effects; ma - modified actions. 
Table 10. Modified CIEP correlation coefficients.

\begin{tabular}{|c|c|c|c|c|c|c|}
\hline & mciep & $m d f$ & $m p$ & $m s$ & mef & $m a$ \\
\hline \multirow[t]{2}{*}{ mciep } & 1 & & & & & \\
\hline & 912 & & & & & \\
\hline \multirow[t]{3}{*}{ mdf } & $0.4717^{*}$ & 1 & & & & \\
\hline & 0 & & & & & \\
\hline & 912 & 912 & & & & \\
\hline \multirow[t]{3}{*}{$\mathrm{mp}$} & $0.3290 *$ & -0.0592 & 1 & & & \\
\hline & 0 & 0.0741 & & & & \\
\hline & 912 & 912 & 912 & & & \\
\hline \multirow[t]{3}{*}{$\mathrm{ms}$} & $-0.7522 *$ & $-0.0939 *$ & $-0.3489 *$ & 1 & & \\
\hline & 0 & 0.0046 & 0 & & & \\
\hline & 912 & 912 & 912 & 912 & & \\
\hline \multirow[t]{3}{*}{ mef } & $0.6564^{*}$ & -0.0049 & $-0.1333^{*}$ & $-0.3454^{*}$ & 1 & \\
\hline & 0 & 0.8835 & 0.0001 & 0 & & \\
\hline & 912 & 912 & 912 & 912 & 912 & \\
\hline \multirow[t]{3}{*}{$\mathrm{ma}$} & $-0.6579 *$ & $-0.2844 *$ & $0.0739 *$ & $0.2839 *$ & $-0.6144 *$ & 1 \\
\hline & 0 & 0 & 0.0257 & 0 & 0 & \\
\hline & 912 & 912 & 912 & 912 & 912 & 912 \\
\hline
\end{tabular}

Legend: mciep - modified CIEP; mdf - modified driving-force; $\mathrm{mp}$ - modified pressure; ms - modified state; mef - modified effects; ma - modified actions.

According to Table 10, the modified driving-force, modified pressure and modified effects have a positive correlation with $m C I E P$, which means that these three dimensions increase environmental damage. The driving-force is formed by single variables that represent elements that cause ecological damage; the pressure represents the burden of negative effects on the ecosystem; and the effects measure the negative impacts on human health. Based on these observations, the relationship between them and economic growth is analysed. The first analysis is performed with each single dimension, and then they are aggregated in factors. Tables 11 to 13 bring together the information about the factors analysis, whilst Table 14 shows the estimated coefficients.

Table 11. Total explained variance of factor analysis.

\begin{tabular}{|c|c|c|c|}
\hline \multicolumn{2}{|c|}{ Factor analysis/correlation } & & ber of obs $=912$ \\
\hline \multicolumn{4}{|c|}{ Method: principal-component factors } \\
\hline \multicolumn{4}{|c|}{ Rotation: orthogonal varimax (Kaiser off) } \\
\hline Factor & Difference & Proportion (\%) & Cumulative (\%) \\
\hline Factor1 & 0.11484 & 0.3771 & 0.3771 \\
\hline Factor2 & 1.01642 & 0.3388 & 0.7159 \\
\hline \multicolumn{2}{|c|}{ LR test: independent $v s$. saturated: } & \multicolumn{2}{|c|}{ Prob $>$ chi $2=0.0002$} \\
\hline
\end{tabular}

The outputs in Table 11 are the explained variance of factor analysis and enlighten how the factors are formed. Two factors $(f 1$ and $f 2)$ are developed from the three dimensions considered. The total variance explained by the two factors created is almost $72 \%$.

Table 12. Factor loadings of the component matrix: driving-force, pressure, and effects dimensions.

\begin{tabular}{lrrr}
\hline Variable & Factor1 & Factor2 & Uniqueness \\
\hline mdf & -0.001 & 0.9602 & 0.0781 \\
$\mathrm{mp}$ & -0.7185 & -0.2512 & 0.4207 \\
$\mathrm{mef}$ & 0.7842 & -0.1773 & 0.3535 \\
\hline
\end{tabular}

Based on Table 12, factor $1(f 1)$ is formed specifically by the contrast between the pressure and the effects dimensions, while factor $2(f 2)$ is constructed mainly by the driving-force. 
Table 13. KMO measure of the sampling adequacy.

\begin{tabular}{|c|c|}
\hline Variable & KMO \\
\hline mdf & 0.4806 \\
\hline $\mathrm{mp}$ & 0.4967 \\
\hline mef & 0.4961 \\
\hline Overall & 0.4951 \\
\hline
\end{tabular}

The KMO overall score is low, but it is still acceptable (it is approximately 0.5 , the lowest limit). Thus, the econometric model can be performed with these factors. Figure 2 shows the plot drawn with the two factors and their corresponding dimensions.

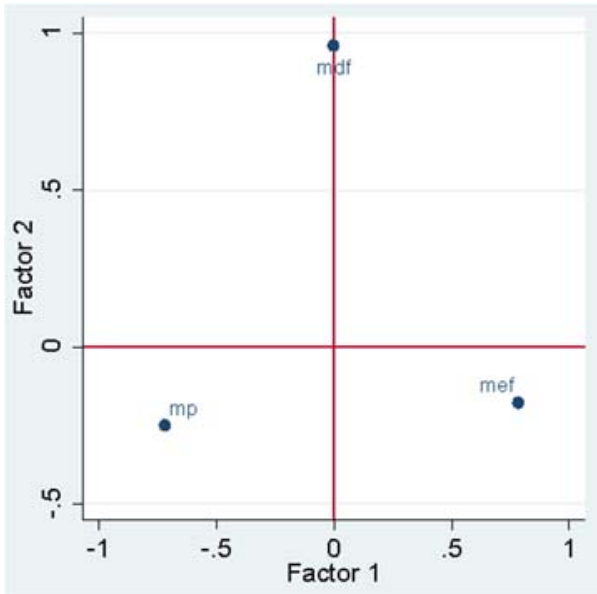

Figure 2. Components plot and the dimensions.

The econometric model is performed using both constructed factors as dependent variables. The estimation outputs are shown in Table 14 (the complete table can be found in Appendix C).

Table 14. Estimated coefficients of the driving-force, pressure, effects and factors.

\begin{tabular}{|c|c|c|c|c|c|}
\hline Variable & gls_mdf & gls_mp & gls_mef & $g l s \_f 1$ & $g l s \_f 2$ \\
\hline gdp & $-.20531419^{*}$ & $-.44493392 * * *$ & $.69103811^{* * *}$ & $5.9825739 * * *$ & -0.09107531 \\
\hline $\operatorname{gdp} 2$ & 0.34754004 & 0.44687701 & $-1.231369 * * *$ & $-9.352259 * * *$ & -0.16597976 \\
\hline gdp3 & -0.09645445 & -0.19644274 & $.6805624 * * *$ & $5.0266098 * * *$ & 1.104665 \\
\hline $\mathrm{dt} 1$ & $-.00829147 * * *$ & $.00183985^{*}$ & $.03370217 * * *$ & $.13461609 * * *$ & $-.07731068 * * *$ \\
\hline $\mathrm{dt} 2$ & $-.00709922 * * *$ & 0.00099002 & $.02665847 * * *$ & $.11072112 * * *$ & $-.06672043 * * *$ \\
\hline $\mathrm{dt} 3$ & $-.00272399 * * *$ & 0.00108944 & $.0195824 * * *$ & $.07418961 * * *$ & $-.03589041 * * *$ \\
\hline $\mathrm{dt} 4$ & $-.00147751 * *$ & $.00190331 *$ & $.0128035 * * *$ & $.04734447 * * *$ & $-.02554456 * * *$ \\
\hline $\mathrm{dt} 5$ & -0.00034725 & $.00175835^{*}$ & $.00623461 * * *$ & $.01596003 * * *$ & $-.01024131^{*}$ \\
\hline dt6 & (omitted) & (omitted) & (omitted) & (omitted) & (omitted) \\
\hline cons & $.24033779 * * *$ & $.69370337 * * *$ & $.43843657 * * *$ & $-1.1912677 *$ & $-.9887705 * * *$ \\
\hline $\bar{N}$ & 906 & 906 & 906 & 906 & 906 \\
\hline EKC Hypothesis & 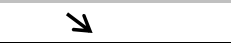 & 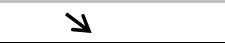 & $\mathrm{N}$ & $\mathrm{N}$ & $\varnothing$ \\
\hline
\end{tabular}

As presented in Table 14, GDP has a negative and significant estimated coefficient with both modified dimensions: driving-force $(m d f)$ and pressure $(m p)$. However, the GDP2 and GDP3 coefficients are not significant. These results mean that the first stage of economic growth reduces the ecological damage and that there is no correlation for other estimated levels of economic growth. Thus, neither driving-force nor pressure supports the EKC hypothesis. Furthermore, the conclusion regarding both dimensions is that the ecological damage decreases at the beginning of economic growth. Morse (2008) achieved distinct results when 
decomposing the Environmental Sustainability Index (ESI) into three dimensions (pressure, state, and response. Indeed, Morse (2008) confirmed the EKC hypothesis with pressure (using the logarithmic model) and state (using the quadratic model).

The modified effects dimension $(m e f)$ and factor $1(f 1)$, which is formed by the pressure and the effects dimensions, have similar correlation outputs. In both estimations, GDP and GDP3 have positive and significant estimated coefficients, while GDP2 has a negative and significant estimated coefficient. These results mean that at the early stages of economic growth, the negative ecological impacts increase. Then, at the second stage, the environmental damage decreases, but it increases again at the third stage of economic growth. Thus, these coefficients do not support the EKC hypothesis; instead, they indicate that in the latest stages of economic growth, environmental damage increases. Accordingly, the plots in both cases have an Nshaped form. Furthermore, GDP does not have any significant coefficient regarding the model performed with factor $2(f 2)$ and thus nothing can be confirmed about the relationship between economic growth and environmental damage through this factor.

\section{Final considerations}

This research aims to analyse the relationship between economic growth and associated environmental impacts, to test the EKC hypothesis. An environmental composite index is used in order to expand the range of information about ecosystem dimensions. The panel data econometric model uses the modified CIEP ( $m$ CIEP) to measure environmental impacts and their connections with economic growth.

According to the Hausman and Breusch-Pagan test results, the fixed effect model is the most indicated regression in this analysis. The empirical outputs show that the $m C I E P$ does not support the EKC hypothesis. The first results are drawn in two forms: firstly, without analysing the economic development level effects, and then taking them into account. One can conclude that, via the $m C I E P$, it is not possible to observe ecological damage decreasing for latest levels of economic growth. In both models the time and individual effects have different correlations with ecological damage.

Complementary estimates are based on the decomposition analysis for the dimensions that increase negative ecological impacts. The results show that the environmental damage, considering the driving-force and the pressure dimensions as dependent variables, is reduced only in the early stages of economic growth. However, it is observed that the negative impact on human health, measured by the effect dimension, increases at the early stages of economic growth, decreases at the second stage, and increases again at the latest stage. The overall conclusion of the decomposition analysis is that the driving force, the pressure and the effects dimensions do not support the EKC hypothesis. These dimensions are aggregated in two factors (by a principal component analysis), to be used as dependent variables representing the environmental damage. The results show that factor 1 has behaviour similar to that of the effects dimension (the ecological damage increases at the early stages of economic growth, then it decreases, only to increase again at the highest stage of economic growth). Factor 2 does not have significant results. Thus, based on the factorial analysis, the EKC hypothesis is also rejected. 
This paper highlights that the EKC hypothesis is not supported by the $m C I E P$ and its dimensions. Instead, some outputs observed that ecological damage increases in the earliest and latest stages of economic growth, decreasing only in the middle zone of economic growth. Thus, this research adds support to the contributions that use environmental composite indexes that are against the theory that economic development positively impacts the ecosystem. However, observing the existing literature, the amount of work already done using environmental composite indexes to test the EKC hypothesis is still scarce. Summing up, future research using composite indexes should consider and be compared with these results. Finally, our findings can be used as a justification for all countries in their aim to control pollution, irrespective of their level of economic development. Furthermore, policy makers should take into account policies that control the accumulated pollutant stocks, and not only pollutant emissions (flows). Therefore, it is critical to be clear that economic growth alone is not enough to improve environmental quality.

\section{Acknowledgements}

The financial support of CAPES (Coordenação de Aperfeiçoamento de Pessoal de Nível Superior) / Brazil is gratefully acknowledged.

\section{References}

Ahmeda, K. and Long, W., 2012. Environmental Kuznets Curve and Pakistan: An Empirical Analysis. Procedia Economics and Finance 1, 4-13.

Abou-Ali H. and Abdelfattah, Y. M. 2013. Integrated paradigm for sustainable development: A panel data study. Economic Modeling 30, 334-342.

Al-Mulali, U., Weng-Wai, C., Sheau-Ting, L., and Mohammed, A. H., 2015. Investigating the environmental Kuznets curve (EKC) hypothesis by utilizing the ecological footprint as an indicator of environmental degradation. Ecological Indicators 48, 315-323.

Arrow, K., Bolin, B., Costanza, R., Dasgupta, P., Folke, C., Holling, C. S., Jansson, BengtOwe, Levin, S., Mdler, Kari-Goran, Perrings, C. and Pimentel, D., 1995. Economic growth, carrying capacity, and the environment. Ecological Economics, 15 (2), 91-95.

Babu, S. S. and Datta, S. K., 2013. The relevance of environmental Kuznets curve (EKC) in a framework of broad-based environmental degradation and modified measure of growth $-\mathrm{a}$ pooled data analysis. International Journal of Sustainable Development \& World Ecology, 20 (4), 309-316.

Beça, T. and Santos R., 2014. A comparison between GDP and ISEW in decoupling analysis. Ecological Indicators 46, 167-176.

Bo, S., 2011. A Literature Survey on Environmental Kuznets Curve. Energy Procedia 5, $1322-1325$.

Boutaud, Aurelien, Natacha Gondran, and Christian Brodhag., 2006. (Local) environmental quality versus (global) ecological carrying capacity: what might alternative aggregated indicators bring to the debates about environmental Kuznets curves and sustainable development? International Journal of Sustainable Development 9 (3), 297-310. 
Brajer, V., R. W. Mead, and F. Xiao., 2011. Searching for an Environmental Kuznets Curve in China's air pollution. China Economic Review 22, 838-397.

Brock, W. A. and Taylor, M. S., 2010.The Green Solow model. Journal of Economic Growth. Vol. 5, 127-153.

Buehn, A. and Farzanegan, M. R., 2013. Hold your breath: A new index of air pollution. Energy Economics 37, 104-113.

Caviglia-Harris, J. L., Chambers, D. and Kahn, J. R., 2009. Taking the "U" out of Kuznets: a comprehensive analysis of the EKC and environmental degradation. Ecological Economics $68,1149-1159$.

Chowdhury R. R. and Moran, E., 2012. Turning the curve: A critical review of Kuznets approaches. Applied Geography 32, 3-11.

CIEP database: http://www.indexciep.org/

Cleveland, C. J., Stern, D. I., and Costanza, R., 2001. The economics of nature and the nature of economics. Edward Elgar Publishing.

Cracolici, M. F; Cuffaro, M.and Nijkamp P., 2010. The Measurement of Economic, Social and Environmental Performance of Countries: A Novel Approach. Social Indicators Research 5, 339-356.

Diakoulaki, D., Mavrotas, G. and Papayannakis, L., 1995. Determining objective weights in multiple criteria problems: The critic method. Computers and Operations Research 22 (7), $763-770$.

Dinda, S. 2005. A theoretical basis for the environmental Kuznets curve. Ecological Economics, 53, 403-413.

Dinda, S. 2004. Environmental Kuznets Curve Hypothesis: A Survey. Ecological Economics $49,431-455$.

Egli, H. and Steger, T. M., 2007. A dynamic model of the environmental Kuznets curve: Turning point and public policy. Environmental and Resource Economics, 36, 15-34.

Fiorino, D. J., 2011. Explaining national environmental performance: approaches, evidence, and implications. Policy Sciences. 44, 367-389.

García-Sánchez, I-M., Almeida, T. A. N. and Camara, R. P. B., 2015. A proposal for a Composite Index of Environmental Performance (CIEP) for countries. Ecological Indicators $48,171-188$.

Grossman G. M. and Krueger A.B., 1991. Environmental impacts of a North American Free Trade Agreement. Working Paper No. 3914. Cambridge (MA): National Bureau of Economic Research.

Inglehart, R., 1995. Public support for environmental protection: The impact of subjective problems and subjective values in 43 societies. PS: Political science and politics 28 (1), $57-$ 71.

Jha, R. and Murthy, K. V. B., 2003. An inverse global environmental Kuznets curve. Journal of Comparative Economics 31, 352-368. 
Kaika, D. and Zervas, E., 2013. The Environmental Kuznets Curve (EKC) theory-Part A: Concept, causes and the $\mathrm{CO}_{2}$ emissions case. Energy Policy 62, 1392-1402.

Koop, G., and Tole, L., 1999. Is there an Environmental Kuznets Curve for deforestation? Journal of Development Economics 58, 231-244.

Kuznets, S., 1955. Economic growth and income inequality. The American Economic Review $45,1-28$.

Lee, C. C., Chiu, Y. B., and Sun, C. H., 2010. The environmental Kuznets curve hypothesis for water pollution: Do regions matter? Chien-Chiang. Energy Policy 38, 12-23.

Li, Y., Chen, C., Wang, Y., and Liu, Y., 2014. Urban-rural transformation and farmland conversion in China: The application of the environmental Kuznets Curve. Journal of Rural Studies 36, 311-317.

Lopez, R. and Mitra, S., 2000. Corruption, Pollution, and the Kuznets Environment Curve. Journal of Environmental Economics and Management 40, 137-150.

Machado, G., Schaeffer, R., and Worrell, E., 2001. Energy and carbon embodied in the international trade of Brazil: an input-output approach. Ecological Economics 39, 409-424.

Mather, A. S., Needle, C. L., and Fairbairn, J., 1999. Environmental Kuznets Curves and forest trends. Geography 84, 55-65.

McPherson, M. A., and Nieswiadomy, M. L., 2005. Environmental Kuznets curves: Threatened species and spatial effects. Ecological Economics 55, 395-407.

Mills, J. and Waite, T. A., 2009. Economic prosperity, biodiversity conservation, and the environmental Kuznets curve. Ecological Economics 68, 2087-2095.

Morse, S., 2008. On the use of headline indices to link environmental quality and income at the level of the nation state. Applied Geography 28, 77-95.

Mozumder, P., Berrens, R. P., and Bohara, A. K., 2006. Is there an environmental Kuznets curve for the risk of biodiversity loss? The Journal of Developing Areas 39, 1-12.

Mukherjee, S., and Chakraborty, D., 2013. Is environmental sustainability influenced by socioeconomic and sociopolitical factors? Cross-country empirical analysis. Sustainable Development 21 (6), 353-371.

OECD, 2008. Handbook on Constructing Composite Indicators: Methodology and User Guide. OECD Publishing, Paris.

OECD, 2011. Economic Environmental and Social Statistics. OECD Publishing, Paris.

Pasten R. and Figueroa E., 2012. The Environmental Kuznets Curve: A Survey of the Theoretical Literature. International Review of Environmental and Resource Economics 6, $195-224$.

Raunikar R. and Buongiorno J., 2008. Ecological integrity as an economic variable: An application to forested landscapes in the southern United States. Journal of Forest Economics $14,29-45$.

Schirnding, Y., 2002. Health in Sustainable Development Planning: The Role of Indicators. World Health Organization (WHO), Geneva. 
Stern, D. I., 2004. The rise and fall of the environmental Kuznets curve. World Development. $32,1419-1439$.

Tevie, J., Grimsrud, K. M., and Berrens, R. P., 2011. Testing the Environmental Kuznets Curve Hypothesis for Biodiversity Risk in the US: A Spatial Econometric Approach. Sustainability 3, 2182-2199.

Thompson, A., 2012. Water abundance and an EKC for water pollution. Economics Letters $117,423-425$.

Tsurumi, T. and Managi, S., 2010. Decomposition of the environmental Kuznets curve: scale, technique, and composition effects. Environmental Economics and Policy Studies 11, 19-36.

Tsuzuki, Y. 2009. Comparison of pollutant discharge per capita (PDC) and its relationships with economic development: An indicator for ambient water quality improvement as well as the Millennium Development Goals (MDGs) sanitation indicator. Ecological Indicators 9, 971- 981 .

Turner, K and Hanley, N. 2011. Energy efficiency, rebound effects and the environmental Kuznets Curve. Energy Economics 33, 709-720.

Wang, Y., Kang, L., Wu, X., and Xiao, Y. 2013. Estimating the environmental Kuznets curve for ecological footprint at the global level: A spatial econometric approach. Ecological Indicators 34, 15-21.

Xiaoyu, L., Jun, Y., and Pengfei, S., 2011. Structure and Application of a New Comprehensive Environmental Pollution Index. Energy Procedia 5, 1049-1054.

Zhao, F., M., Xu, Zheng, Y., Wong, M. H. G., and Chi, Y., 2013. Improving the environmental Kuznets curve for evaluating the relationships between carbon dioxide emissions and economic development. Journal of Food, Agriculture \& Environment 11 (2), 1193-1199.

Yeo, I., Johnson, R.A., 2000. A new family of power transformations to improve normality or symmetry. Biometrika 87 (4), 954-959. 